$10-1-2012$

\title{
The Association of Elevated 2',5'-Oligoadenylate-Dependent \\ RNase L with Lung Cancer Correlated with Deficient Enzymatic Activity and Decreased Capacity of RNase L Dimerization
}

Huijing Yin

Tongji University School of Medicine

Aimin Zhou

Cleveland State University, A.ZHOU@csuohio.edu

Yalei Dai

Tongji University School of Medicine

Follow this and additional works at: https://engagedscholarship.csuohio.edu/scichem_facpub

Part of the Chemistry Commons

How does access to this work benefit you? Let us know!

\section{Recommended Citation}

Yin, Huijing; Zhou, Aimin; and Dai, Yalei, "The Association of Elevated 2',5'-Oligoadenylate-Dependent RNase L with Lung Cancer Correlated with Deficient Enzymatic Activity and Decreased Capacity of RNase L Dimerization" (2012). Chemistry Faculty Publications. 421.

https://engagedscholarship.csuohio.edu/scichem_facpub/421

This Article is brought to you for free and open access by the Chemistry Department at EngagedScholarship@CSU. It has been accepted for inclusion in Chemistry Faculty Publications by an authorized administrator of EngagedScholarship@CSU. For more information, please contact library.es@csuohio.edu. 


\title{
The association of elevated $2^{\prime}, 5^{\prime}$-oligoadenylate-dependent RNase $L$ with lung cancer correlated with deficient enzymatic activity and decreased capacity of RNase L dimerization
}

\author{
Huijing Yin , Aimin Zhou , Yalei Dai
}

\section{Introduction}

Lung cancer is the most common cause of cancer deaths in the world with over one million new cases diagnosed per year [1]. The etiology of lung cancer has been shown to be multifactorial, including genetic, epigenetic, and environmental factors such as tobacco smoking. Although smoking remains the most important etiological factor which associated with more of $90 \%$ of cases of lung cancer [2], accumulating evidence has showed that genetic factors may modify the risk of lung cancer. There is a clear role for genetics since only $15 \%$ of lifetime smokers develop lung cancer and $10 \%$ of lung cancers occur in never-smokers especially in women [3] and in Asiatic women in particular [4]. Thus, a growing body of evidence has shown the role of genetic background in lung cancer susceptibility, progression, and prognosis [5-8]. Genetics studies support the RNase L gene as a strong candidate for hereditary prostate cancer 1 (HPC1) allele [9,10]. Increasing genetic and functional studies have revealed a strong association between defects in endoribonuclease L (RNase L) activity owing to mutation or dysfunction and increased risk of cancer such as prostate cancer $[11,12]$ and colorectal cancer $[13,14]$.

RNase $\mathrm{L}$ functions in the $2^{\prime}, 5^{\prime}$-linked oligoadenylates (2-5A) system of interferon (IFN) action against viral infection and cell proliferation. The 2-5A system mediates host defense against certain types of viral infections. Cells overexpressing RNase L can overcome viral infection [15]. In contrast, overexpression of a dominant negative mutant of RNase L results in increased susceptibility to viral infection [16]. In vivo studies showed that mice containing targeted disruption of RNase L gene succumbed to encephalomyocarditis infection more rapidly than infected wild type mice $[17,18]$. The mechanism of RNase L acting as a candidate of tumor suppressor is thought to involve the selective regulation of mRNAs encoding proliferation-stimulatory or cytostatasis/cell death-inhibitory proteins. The different RNA substrates of RNase L have been identified such as IFN or PKR $[19,20]$. It has been reported that alphavirus-based DNA vaccine against a non-mutated tumorassociated self-antigen (tyrosinase-related protein-1, TRP-1) was severely impaired in RNase L null mice, indicating that RNase L has functions in host immune system against cancer [21]. RNase L activity is modulated by a member of the ATP-binding cassette $(A B C)$ transporter protein, such as RNase L inhibitor (RLI)-HP68, now classified as $A B C E 1$ protein [22]. Interestingly, the expression levels of ABCE1 mRNA and protein were elevated in lung adenocarcinoma tissues [23]. A clinical study showed that the level of RNase in serum was significantly higher in patients with lung carcinoma 
A
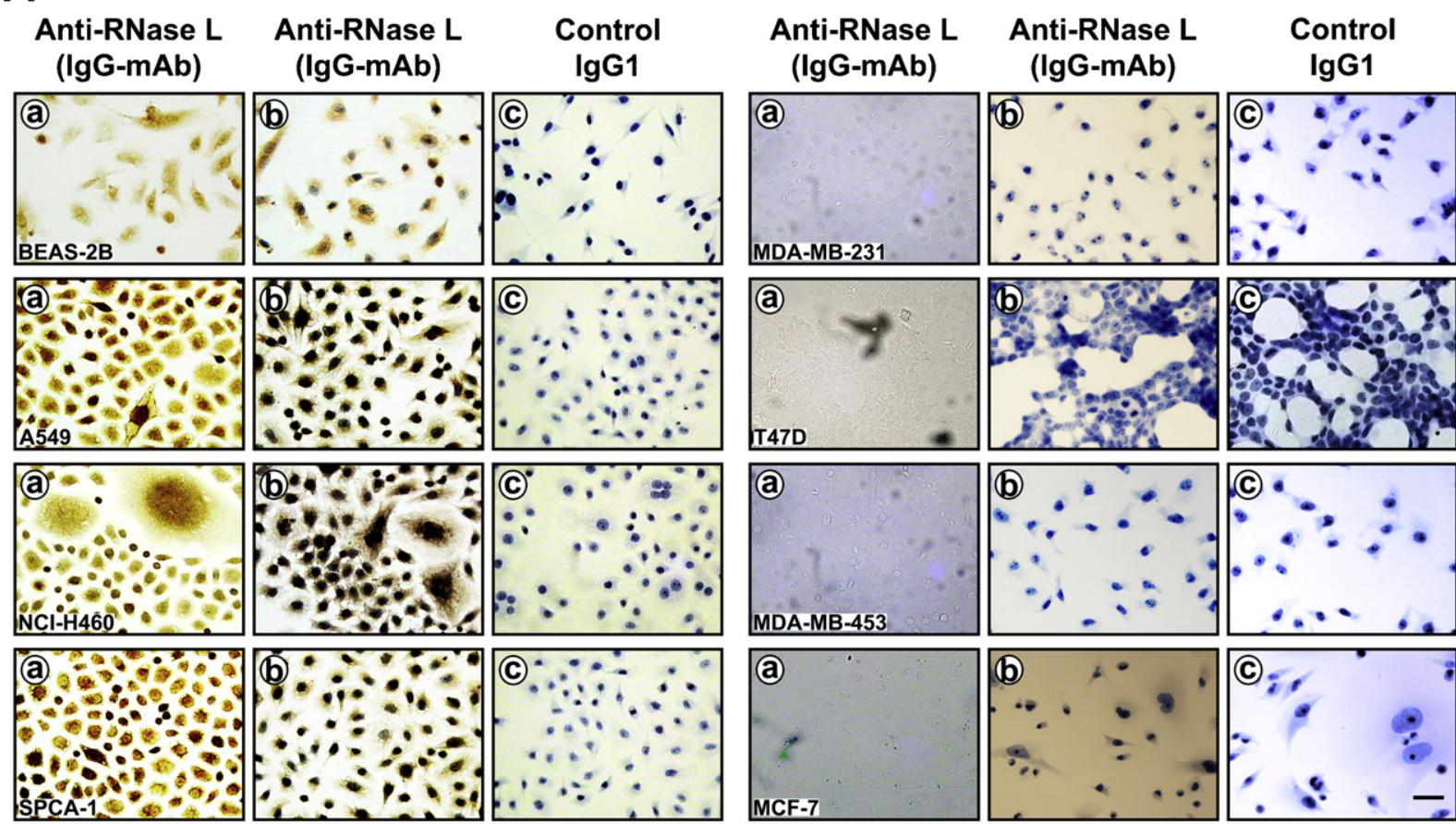

Hematoxylin(-)

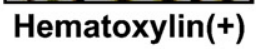

Hematoxylin(+)
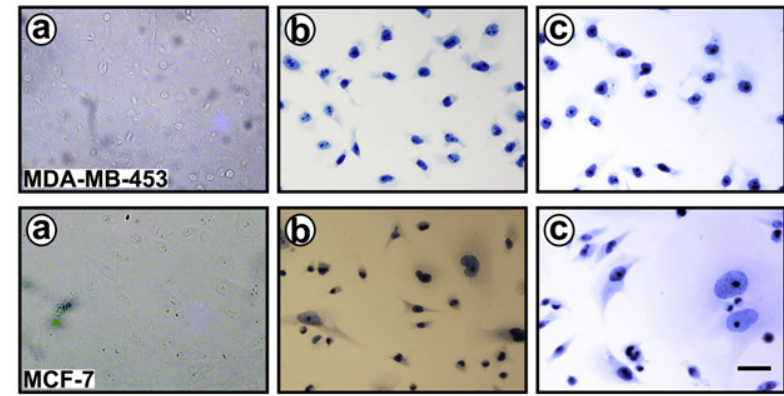

Hematoxylin(-)

Hematoxylin(+)

Hematoxylin(+)

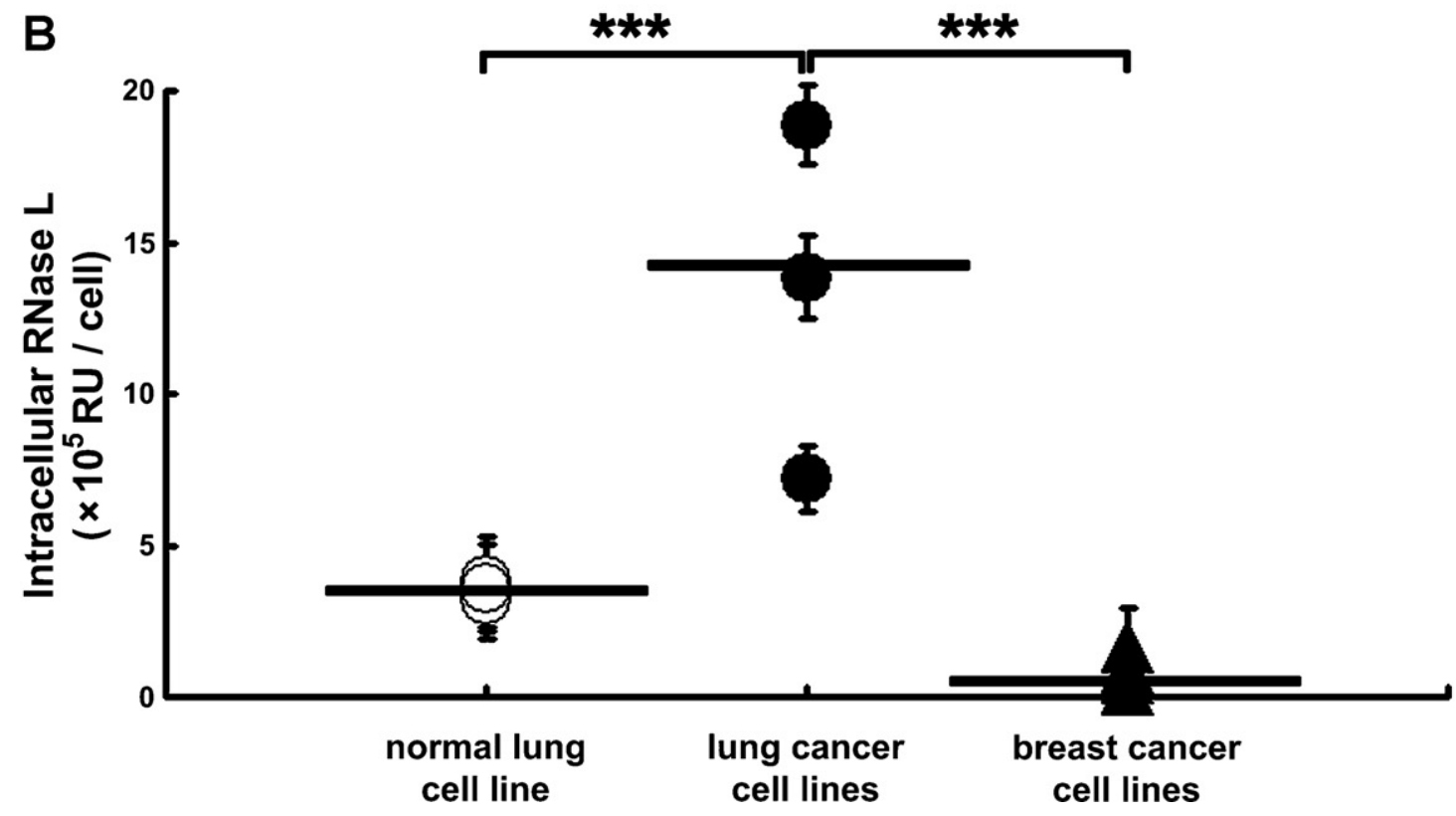

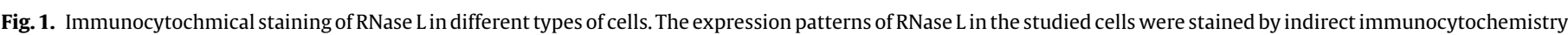

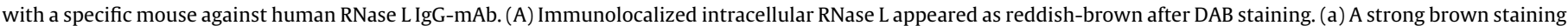

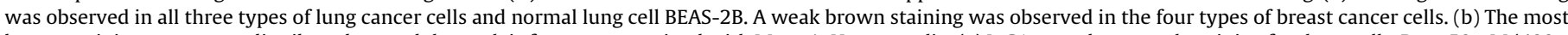

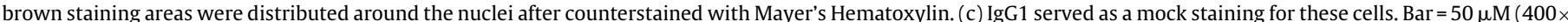

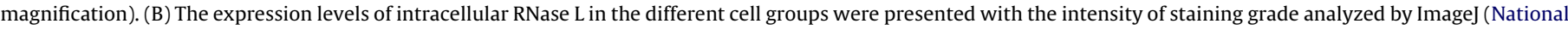
Institutes of Health, USA). The data were from three independent experiments and presented as mean \pm S.D. ${ }^{* * *}$ indicates $P<0.001$ between two groups.

compared with healthy nonsmokers [24] although which category of RNase was increased is unclear. The physiological significance of the observations in lung cancer remains largely unknown.

In the present work, we determined the differential expression of RNase L in various cell types and found that RNase L is highly expressed in lung cancer cells with significantly decreased enzymatic activity due to an increase of RLI. Our findings provide a further understanding of how lung cancer cells escape growth regulating mechanisms to form a tumor.

\section{Materials and methods}

\section{Cells culture and transfection}

The human cell lines used in this study were purchased from the Shanghai Institute of Cell Biology (China) including lung adenocarcinoma cell lines (A549, NCI-H460 and SPCA-1), breast carcinoma cell lines (MDA-MB-231, T47D, MDA-MB-453 and MCF-7), and normal lung cell line BEAS-2B and blood monocyte cell line THP-1. 
A

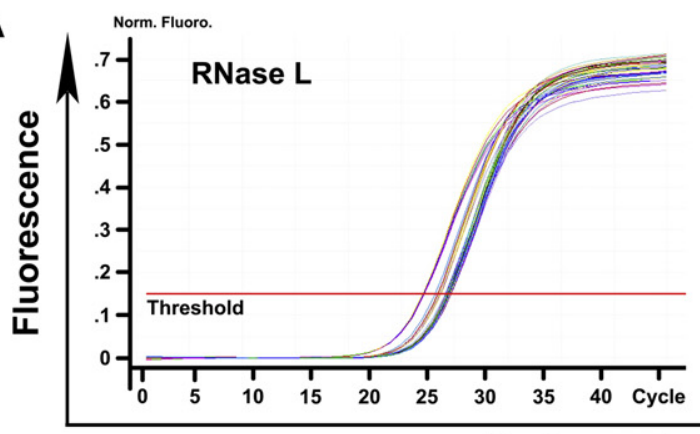

Norm. Fluoro.

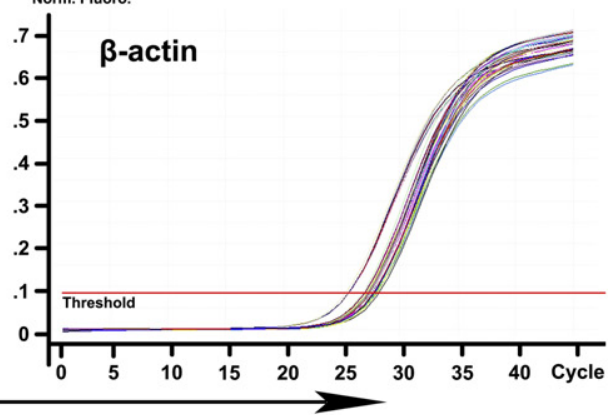

Cycle number

B
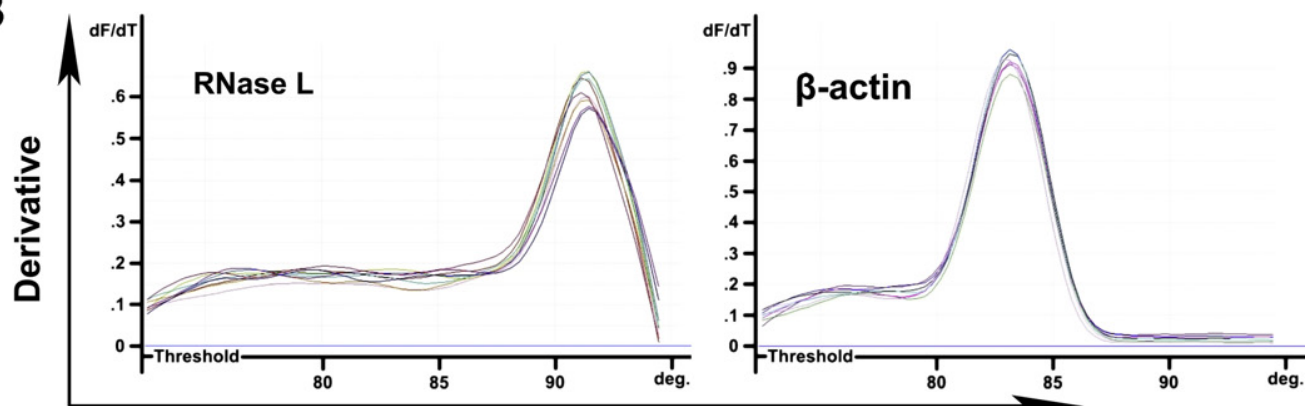

Temperature

C
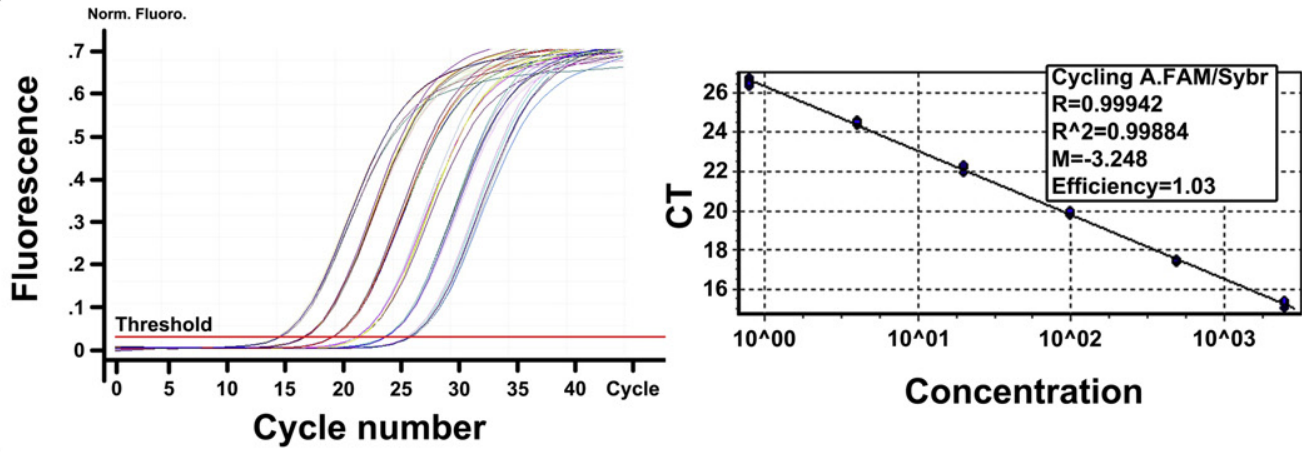

D

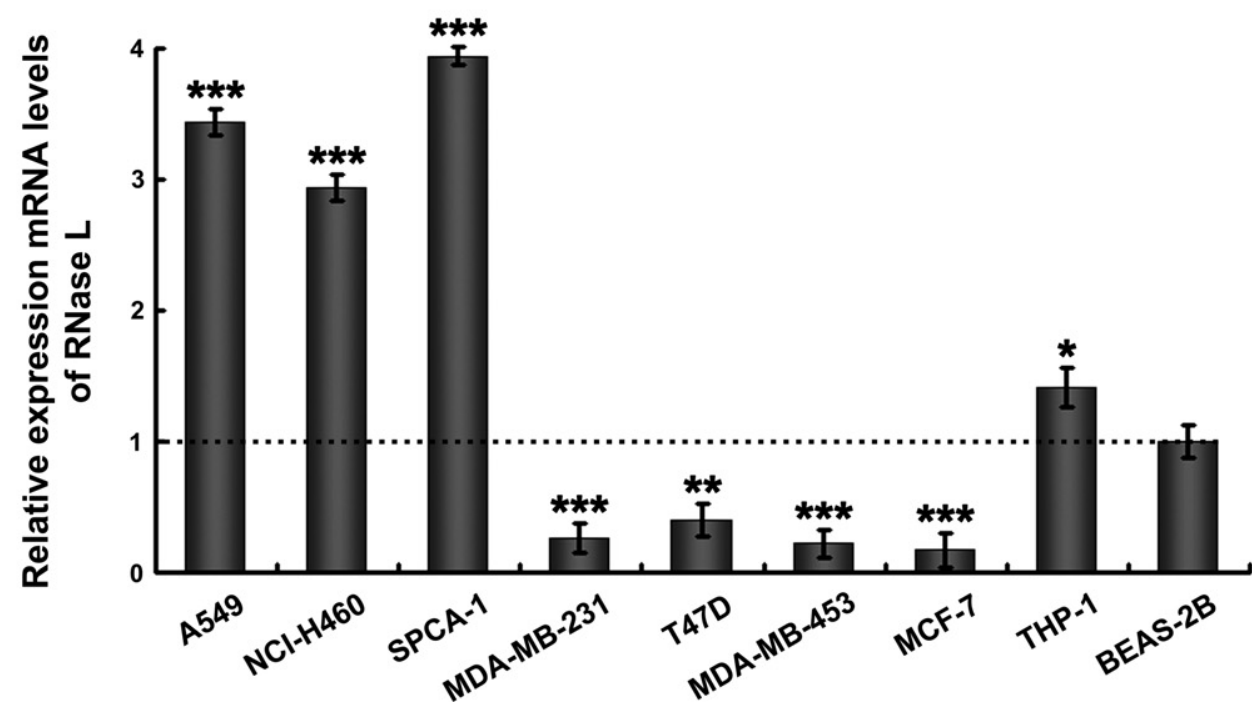

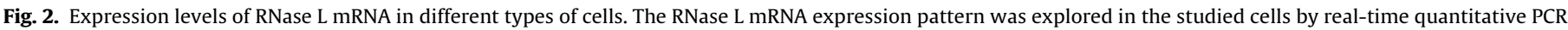

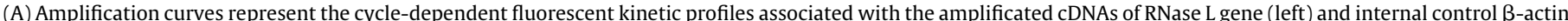

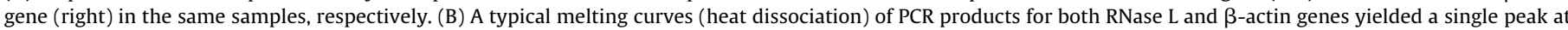

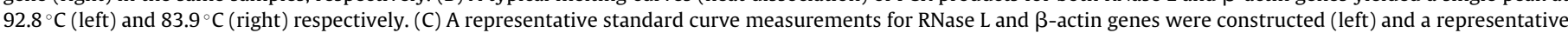

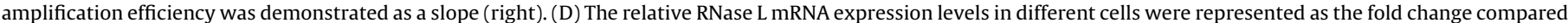

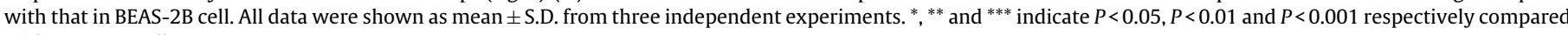
with BEAS-2B cell. 
The cells were grown in RPMI 1640 medium or DMEM containing 10\% FBS (Gibco). Cell transfection with pEGFP-N3 recombinant plasmid containing wild-type RNase L was carried out by using lipofectAMINE reagent (Invitrogen) according to the manufacturer's instruction.

\section{Immunocytochemistry staining}

An Avidin-Biotin-Peroxidase Complex (ABC) method was used to localize/visualize the protein expression of RNase $L$ in the cells. Cells were incubated with the mouse anti-human RNase L antibody (from Dr. Zhou Lab), before incubation with biotinylated goat antimouse IgG, and followed by incubation with streptavidin-avidin horseradish peroxidase (HRP). DAB substrate was used for developing brown reaction products and Mayer's Hematoxylin was used to counterstain nuclear. Mouse anti-human IgG1 served as a negative control. The cells images were obtained under a light microscope (Motic, BA300, Germany).

\section{Quantitative real-time PCR}

Total RNAs from the cells were isolated using Trizol reagent (Invitrogen). RNA reverse transcription was carried out by using ImProm-II ${ }^{\mathrm{TM}}$ reverse transcription kit (Promega) according to the manufacturer's instruction. The cDNA was subsequently analyzed in the qPCR run on the Corbett Rotor-Gene 3000 (Corbett Research) by using SYBR ${ }^{\circledR}$ Premix Ex TaqTM II kit (Takara) and the real-time PCR primers designed as follows: 5'-CTTAAGGCCCAGGACTGTGGAG-3' and 5'-TCCATCACTACAGATCCAGCAAGAG-3' for RNase L (NM_021133); 5'-CCAAGCGCCTATGGAGTTGTC-3' and 5'-TCATTTGCTGTCTCAGCCACTTTA-3' for RLI (NM_001040876.1), and 5'-ATTGCCGACAGGATGCAGA-3' and 5'-GAGTACTTGCGCTCAGGAGGA-3' for $\beta$-actin (NM_001101.3). The absence of primer-dimer formation for each oligonucleotide set was validated by establishing the melting curve profile. The gene expression levels were calculated by $\Delta \Delta C T$ method.

\section{Western blotting}

The equal amounts of proteins were separated using 12\% SDSPAGE electrophoresis and electransferred onto PVDF membrane. The membranes were blocked with $5 \%$ milk before incubation with mouse anti-human RNase L and RLI antibodies (ProSci) for detection RNase L and RLI respectively. The blots were developed with ECL system and exposed to X-ray film (Eastman Kodak) after incubation with goat anti-mouse horseradish peroxidase-conjugated secondary antibody (Jackson). The internal control for normalizing the protein, $\beta$-actin, was detected by incubation with mouse anti- $\beta$-actin antibody followed by goat anti-mouse horseradish peroxidase-conjugated secondary antibody.

\section{2-5A synthesis and treatment}

$2-5 \mathrm{~A}\left[\mathrm{p}_{3}\left(\mathrm{~A} 2^{\prime} \mathrm{p}\right)_{n} \mathrm{~A}\right.$, where $n=1$ to $\left.\geq 3\right]$ was prepared enzymatically from ATP by using recombinant $2^{\prime}, 5^{\prime}$-oligoadenylate synthetase $1(40 / 46 \mathrm{kDa}$ ) (Abnova). Briefly, reaction mixture including OAS1 buffer [20 mM HEPES (pH 7.6), 20 mM magnesium acetate, $20 \mathrm{mM} \mathrm{KCl}$ and $1 \mathrm{mM}$ EDTA], $20 \mu \mathrm{g} / \mathrm{ml}$ human full-length recombinant protein OAS1, $10 \mathrm{mM}$ ATP (pH 7.4) (Cell Signaling Technology) and $1 \mu \mathrm{g} / \mathrm{ml}$ poly (I:C) (InvivoGen), was incubated at $37^{\circ} \mathrm{C}$ for $24 \mathrm{~h}$. The synthesized 2-5A was harvested by centrifugation at $3,000 \mathrm{~g}$ for 15 min through a Centricon-10 filter (Millipore Corp.) to separate from reaction mixture. The freshly synthesized 2-5A was diluted into $100 \mathrm{nM}$ with Opti-MEM medium (Invitrogen) and mixed with

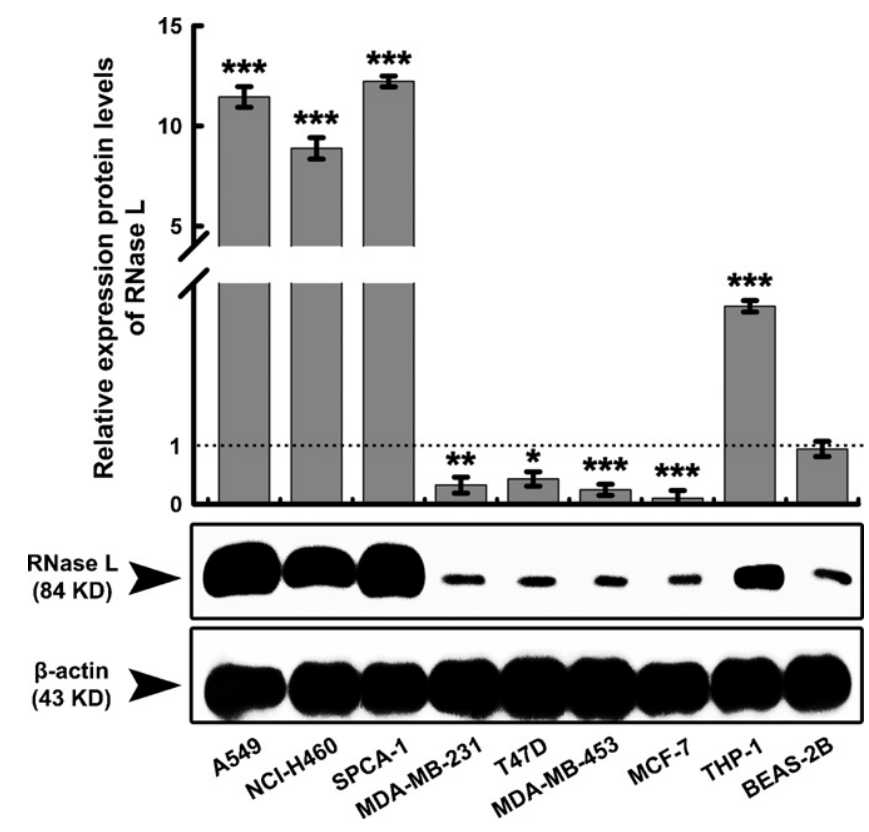

Fig. 3. Expression levels of RNase L protein in different types of cells. The expression protein levels of RNase L were detected in the studied cells by western blotting with a specific mouse against human RNase L IgG-mAb. A typical expression pattern of RNase $L$ protein levels was shown by western blotting. The protein level of $\beta$-actin served as the internal control. The relative RNase L protein expression levels in the different cells were presented as the fold change compared with that in BEAS-2B cell. The data were shown as mean \pm S.D. from three independent experiments. * ** and ${ }^{* * *}$ indicate $P<0.05, P<0.01$ and $P<0.001$ respectively compared with BEAS-2B cell.

calcium phosphate for $20 \mathrm{~min}$, then applied to the cells for the indicated time for RNase L functional study.

\section{Detection of RNase L activity}

Total RNA was isolated from the cells using Trizol reagent followed by chloroform extraction and isopropanol precipitation. After washed with 70\% ethanol, the RNA was dissolved in Tris- $\mathrm{HCl}$ ( $\mathrm{pH}$ 7.5) buffer containing $5 \mathrm{mM} \mathrm{MgCl} 2$ and $0.1 \mathrm{mM} \mathrm{CsCl}$. The ribosomal peak areas of $28 \mathrm{~S}$ and $18 \mathrm{~S}$ rRNA and cleavage products were visualized under UV light after staining with ethidium bromide. RNase L activity was determined by measuring the percentage of rRNA cleavage products [25].

\section{RNase L dimerization assay}

After incubation, cells were treated with cocktails-mixture of protease and phosphatase inhibitors for $10 \mathrm{~min}$ before lysed in icecold non-denaturing lysis buffer [20 mM Tris- $\mathrm{HCl}$ pH 8.0, $137 \mathrm{mM}$ $\mathrm{NaCl}, 10 \%$ glycerol, $1 \% \mathrm{NP}-40,2 \mathrm{mM}$ EDTA]. The protein pellets were incubated with $5 \mathrm{mg} / \mathrm{ml}$ dimethyl suberimidate (Fluka) for $30 \mathrm{~min}$ and immediately terminated with loading buffer before boiled at for $5 \mathrm{~min}$ to denature the protein. Then proteins were separated by $8 \%$ SDS-PAGE and applied to western blot analysis.

\section{Statistical analysis}

All experiments were repeated at least three times. Data were expressed as the mean \pm S.D. and statistical analyses between groups were performed using a one-way ANOVA, followed by the paired Student's $t$-test. The differences were considered statistically significant when $P<0.05$. 
A

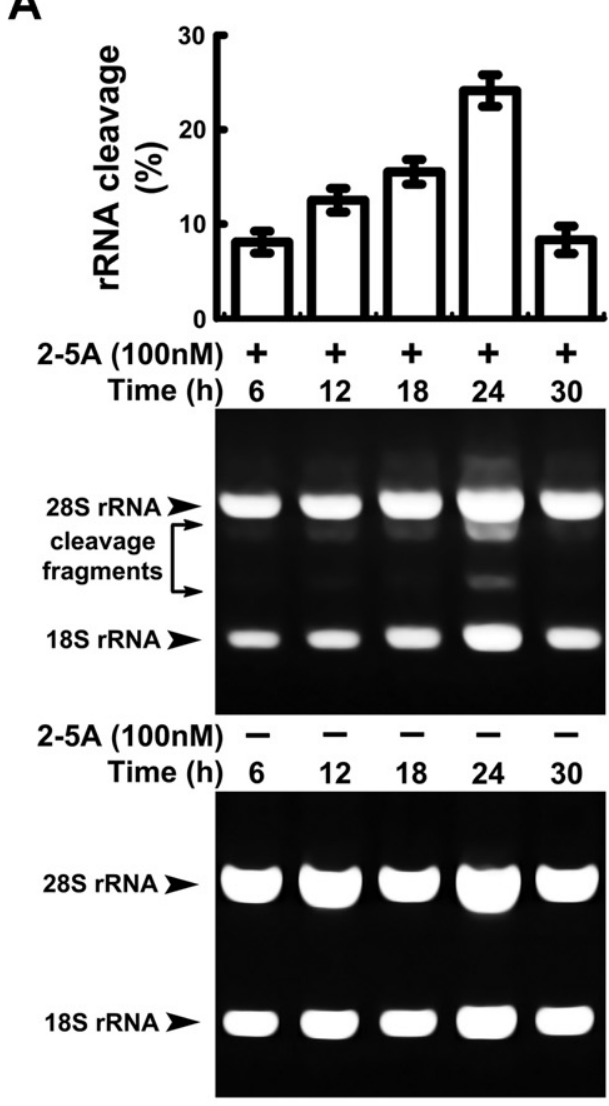

C

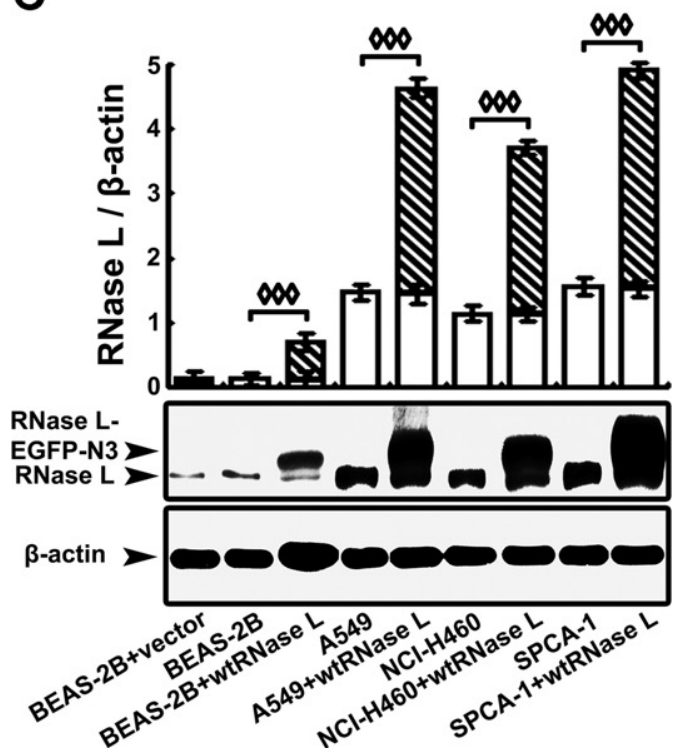

B

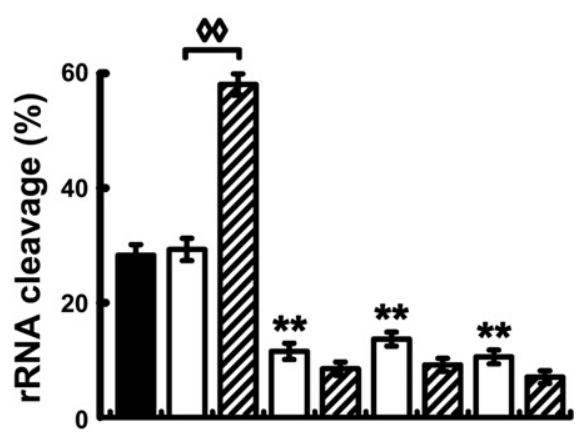

2-5A (100nM) +++++++++
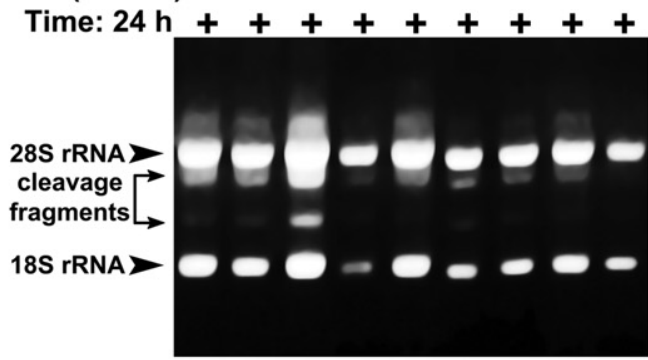

2-5A (100nM) - - - - - -

Time: $24 \mathrm{~h}+\boldsymbol{+}+\boldsymbol{+}+\boldsymbol{+}+\boldsymbol{+}$
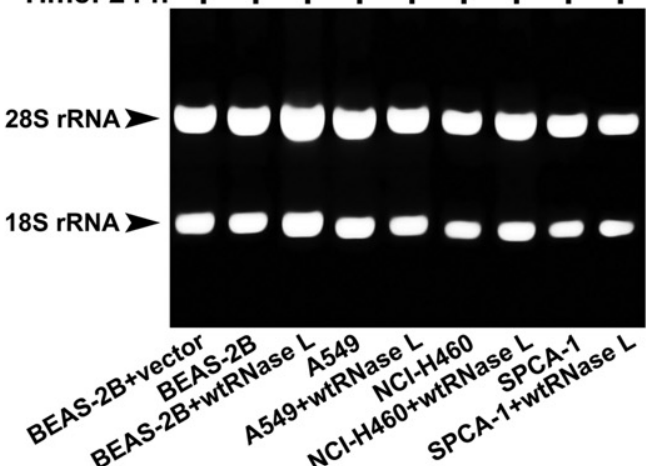

D

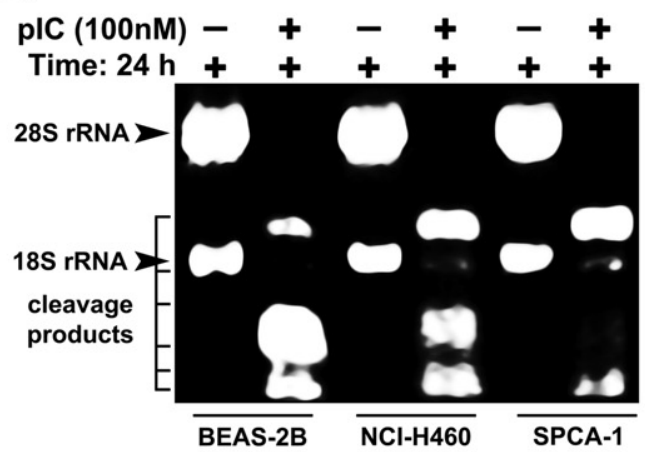

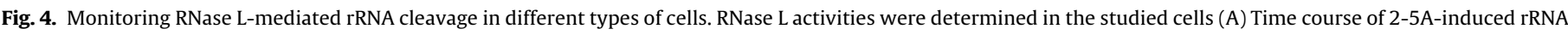

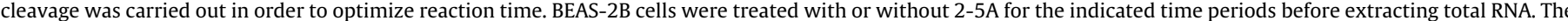

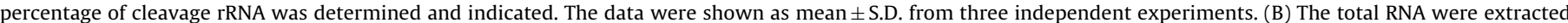

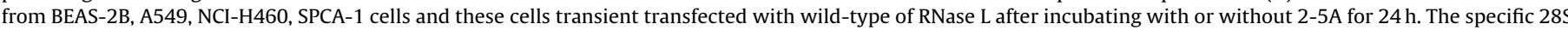

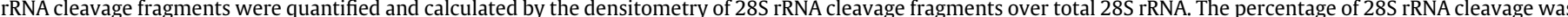

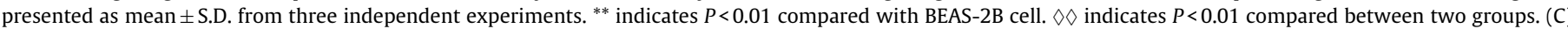

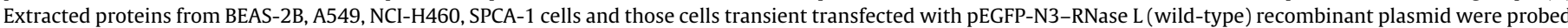

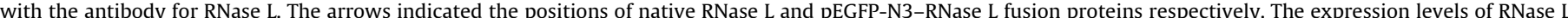

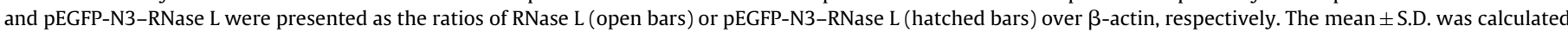

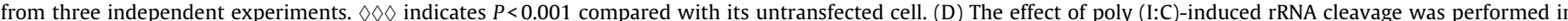

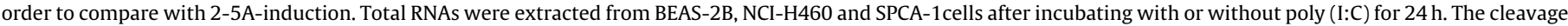
products of rRNA were observed and indicated. 


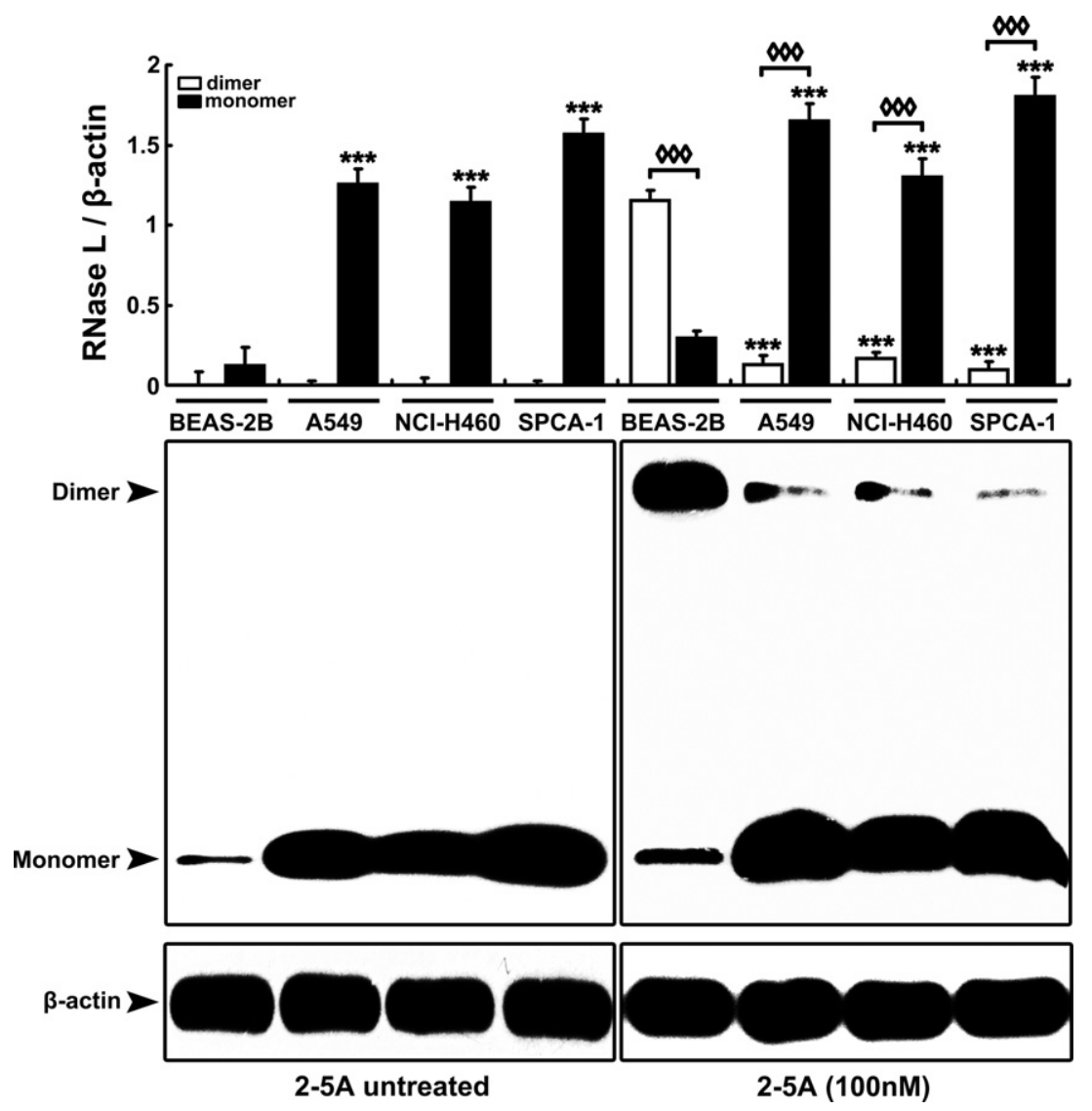

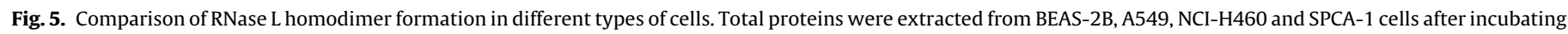

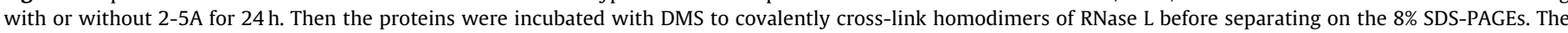

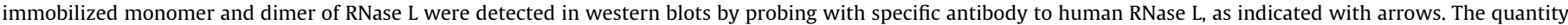

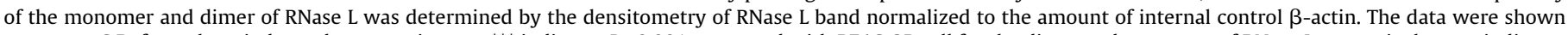

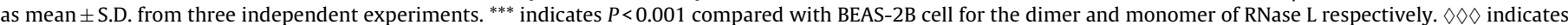
$P<0.001$ between the two group.

\section{Results}

To determine the expression of RNase $\mathrm{L}$ in lung cancer cells, we performed immunocytochemical staining to examine the RNase $\mathrm{L}$ protein levels in several types of lung cancer cells in compared to that in breast cancer cells and normal lung cells. As shown in Fig. 1A, a strong positive staining was observed in the three types of lung cancer cells (Fig. 1A(a)), which were apparently distributed around nuclei of the cells (Fig. 1A(b)). In contrast, RNase L was much less expressed in breast cancer cells and normal lung cells examined. The average level of RNase L expression in the lung cancer cells $\left(13.9 \times 10^{5} \mathrm{RU} /\right.$ cell $)$ was about 4.3 - and 17.3 -fold of that in normal lung cells $\left(3.2 \times 10^{5} \mathrm{RU} /\right.$ cell $)$ and breast cancer cells $\left(0.8 \times 10^{5} \mathrm{RU} /\right.$ cell) respectively (Fig. $\left.1 \mathrm{~B}\right)$. Further to determine at which level of RNase L is up-regulated, the RNase L expression in mRNA and protein levels were examined by using qPCR and western blot analysis. The mRNA and protein levels of RNase $\mathrm{L}$ were increased to 3.44- and 11.4-fold in A549 cells, 2.94- and 8.9-fold in NCI-H460 cells, and 3.94- and 12.2-fold in SPCA-1 cells respectively compared with that in the corresponding normal lung cells (Figs. 2 and 3 ). Whereas in the breast carcinoma cells, the expression levels of RNase $L$ mRNA and protein were remained low which were consistent with immunocytochemical staining results (Fig. 1A). The up-regulated RNase L mRNA expression pattern was also found in other types of lung cancer cells, such as NCI-H157, GLC-82, Calu-3, LTEP-s, NCI-H520, NCI-H209 and PG-LH7 (data not shown). These results were consistent with previous observation that RNase L is found to be highly expressed in some types of cancer cells such as prostate cancer [11,12] and colorectal cancer [13,14]. The physiological significance of the aberrant expression of RNase $L$ in cancer cells remains unknown although the expression of RNase L in the lung cancer cells is up-regulated at both transcriptional and translational levels (Figs. 2 and 3).

It have been reported that an increased expression of RNase L may be associated with the RNASE $L$ gene mutation in prostate cancer cells $[12,26]$. However, we have not found any mutation in RNASE L gene that cloned from the lung cancer cells (A549, NCI-H460 and SPCA-1) by using the nest PCR technique (data not shown). We next examined RNase L enzymatic activity by measuring rRNA cleavage in these cells induced by $2-5$ A (Fig. 4). The time course shows that the maximal 28S rRNA cleavage appeared at $24 \mathrm{~h}$ in BESA-2B cells after treatment with 2-5A (Fig. 4A). Interestingly, the percentages of $28 \mathrm{~S}$ rRNA cleavage in the cancer cells treated with $2-5 \mathrm{~A}$ under the same condition were significantly reduced compared with that in BESA-2B cells (Fig. 4B, open bars) although the RNase $L$ protein levels in the cancer cells were significantly higher (Fig. 3). In order to examine the effects of aberrantly expressed RNase $\mathrm{L}$ in the lung cancer cells, the pEGFP-N3-RNASE L (wild-type) plasmid was constructed and transfected into the cancer cells and BESA-2B cells. As shown in Fig. 4C, the expression of pEGFP-N3-RNase L was ectopically increased about 3-fold in BESA-2B cells as well as in the three types of lung cancer cells. Surprisingly, the RNase Lactivity in transfected lung cancer cells barely changed after the cells were induced with 2-5A for $24 \mathrm{~h}$ (Fig. 4B, hatched bars). However, the increased level of RNase L activity in BESA-2B cells was consistent with the increase of the RNase $\mathrm{L}$ 
protein after the cells were transfected with the construct. Interestingly, the rRNAs cleavage patterns in the cancer cells induced by poly(I:C) were different from that by $2-5 \mathrm{~A}$ (Fig. 4D). Taken together, our data suggest that there may be an inhibitor which is able to inhibit RNase $\mathrm{L}$ activation in lung cancer cells.

Since dimerization of RNase $\mathrm{L}$ induced by $2-5 \mathrm{~A}$ is an indispensable step for its enzyme activation to cleavage rRNA [27], we examined whether high expressed RNase $\mathrm{L}$ in the lung cancer cells is able to form a dimer in response to 2-5A binding. It is surprising the ability of RNase L dimerization in these lung cancer cells was remarkably reduced in comparison with that in BESA-2B cells (Fig. 5). The results distinctly implicate that the dysfunction in RNase L activity was due to that RNase L was unable to form a dimer in these lung cancer cells. It has been well established that RNase $\mathrm{L}$ activity can be regulated by RLI, a specific inhibitor of RNase L. RLI functions as a regulatory protein to inhibit RNase L molecule interaction from forming a dimer, resulting in a reduction of RNase $\mathrm{L}$ activation for cleaving rRNA induced by 2-5A [22]. To determine whether 2-5A induces RLI synthesis, the expression of RLI in these lung cancer cells and normal lung cells were examined. Interestingly, the expression of RLI in the lung cancer cells was significantly higher than that in normal lung cells after incubation with 2-5A. Quantitative analysis revealed that the both levels of RLI mRNA and protein were significant increased in the lung cancer cells compared with that in BEAS-2B cell (Fig. 6). More interestingly, the level of RLI was significantly reduced in BEAS-2B cells after induced with $2-5 \mathrm{~A}$ while the reverse results were observed in the cancer cells. The results suggest that the dysfunctional activity of RNase L in lung cancer cells may be caused by aberrantly expressed RLI that interrupts dimerization of RNase $\mathrm{L}$.

\section{Discussion}

It has been well established that RNase L plays an important role in regulating cellular senescence, cellular proliferation, and cell survival. Aberrant expression of RNase L can either promote cell death or result in enhanced susceptibility to microbial infections and cancer $[28,29]$. Emerging evidence suggests that RNase $\mathrm{L}$ expression in cancer cell may represent an important prognostic marker to predict disease outcome for cancer patients. In this study, we have presented evidence showing that although RNase L is highly expressed in lung cancer cells, RNase L cannot be activated as a result of failure of dimerization caused by up-regulation of RLI expression. Our finding provides new insight into how cancer cells escape the antiproliferative mechanism in the host to form a tumor, which may be useful for the design of novel strategies for treating lung cancer through regulating RNase L activity.

RNase $\mathrm{L}$ is associated with an increased risk of carcinoma of the uterine cervix, and carcinomas of head and neck squamous cell reveal a strong association between defects in RNase L activity and tumorigenesis [30]. To elucidate the potential role of RNase L in lung carcinomas, we examined its expression pattern and function in the A549, NCI-H460 and SPCA-1 lung cancer cells. As expected, the RNase L activities in the lung carcinomas cells were deficient. Interestingly, the lack of RNase L activity was not correlated with gene mutations but attributed to a reduction of RNase L dimerization as a catalytically active form. To date, the reason for the defect of RNase $\mathrm{L}$ in cancer is supported by the identification of different mutations (M1I, E265X, 471_AAAG, and R462Q) with disease onset and/or frequency $[10,11]$. However, our results have found a rare phenomenon that there was no obvious gene alteration accounted for RNase L defect, which may offer a new cause to the inactivation of RNase L in cancer.

To further explore the correlation between the expression and function of RNase L, overexpression of wild-type of full-length
A

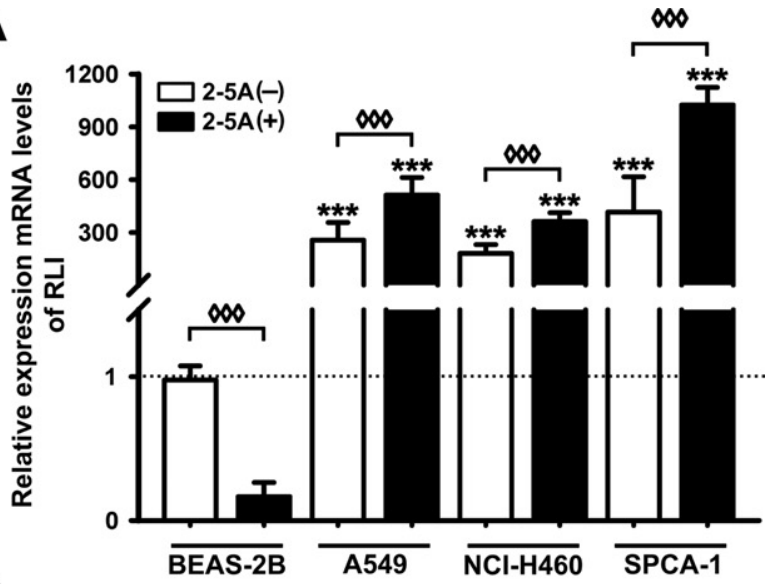

B
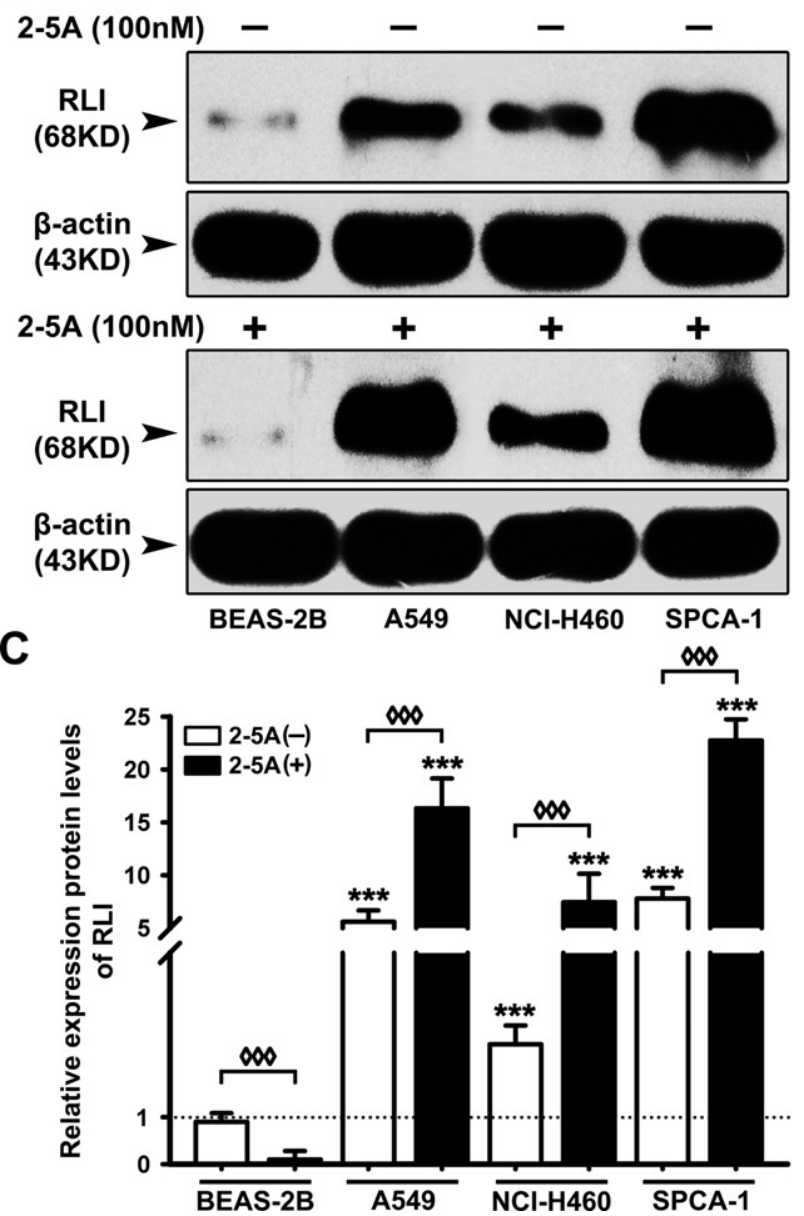

Fig. 6. Expression of RLI mRNA and protein levels in different types of cells. RLI levels were detected in BEAS-2B, A549, NCI-H460, and SPCA-1 cells after incubating with or without 2-5A for $24 \mathrm{~h}$. (A) The RLI mRNA expression pattern was explored by real-time quantitative PCR. The transcript amount of RLI mRNA was normalized with $\beta$-actin mRNA. The levels of relative RLI mRNA expression in the cells were represented as the fold change compared with untreated BEAS-2B cell. (B) The expression protein levels of RLI in the same samples were detected by western blotting with RL antibody and normalized to the amount of $\beta$-actin presented. The relative RLI protein expression levels in the cells after treating with or without 2-5A were calculated by the fold change compared with untreated BEAS-2B cell. All data were shown as mean \pm S.D. from three independent experiments. ${ }^{* * *}$ indicates $P<0.001$ compared with untreated BEAS-2B cell. $\diamond \diamond \diamond$ indicates $P<0.001$ between two groups.

RNASE L in the lung cancer cells were studied. Unexpectedly, RNase L cleavage activity was reduced in the cancer cells expressed higher levels of RNase L. The results suggested the correlation between the function of RNase $L$ and the expression level of RNase 
L was inversely related. The absence of mutations suggests that the decreased activity may be involved in the protection mechanism of lung cancer cells against RNase L activity, which may promote cancer cell growth. RLI can form a heterodimer with RNase L and inhibit the binding of 2-5A by RNase $\mathrm{L}$ in a noncompetitive manner [22]. Some viruses could recruit a host protein to inhibit RNase L activity, which is the case for EMCV and HIV-1 that lead to increased expression of RLI [31,32]. Our results also demonstrated that RNase $\mathrm{L}$ cannot be activated as a result of failure of dimerization caused by the upregulation of RLI expression.

Interestingly, different cancer cells may escape the growingregulatory mechanism to form a tumor through their unique strategy. For example, the etiology of hereditary prostate cancer has been found to be correlated with the RNase L gene mutation. Functional analysis or epidemiologic study of the role of RNASEL in hereditary prostate cancer has been observed in most, but not all, studies [9,10]. The R462Q variant of RNase L, which has an attenuated enzymatic activity, is found in up to $13 \%$ of prostate cancer cases [33]. Individuals heterozygous for these mutations exhibit a $150 \%$ increased risk of prostate cancer, and homozygotes have greater than double of the risk, underscoring the importance of inactivating RNase $\mathrm{L}$ in the development of this disease [34]. RNase L is also found to be highly expressed in colon cancer tissues compared with that in their paired normal tissues. Although purified RNase L from colorectal tumor tissues by using 2-5A affinity resin is functional, it is possible that non-covalent binding inhibitors of RNase L may have been removed during the purification process [14]. In addition, it has been reported that there is an RNase L inhibitor binding with RNase $\mathrm{L}$ to prevent the turnover of mRNA-protein (mRNP) by RNase L in the cytoplasm of human placenta [35]. Collectively, these observations implicate that RNase L, a growing regulator, may be inhibited by distinct inhibitors in different microenvironment.

\section{Conclusion}

Tumor formation is a net outcome of the balance of suppression and proliferation in cancer cells. Cancer cells must suppress all growing-regulatory mechanisms including RNase L in order to form a tumor although the molecular basis underlying the phenomena remains largely unknown. Up-regulation of RNase $\mathrm{L}$ in lung cancer cells may be due to such a feedback response. The growing-regulatory machinery in the cells attempt to counteract the proliferative effect by promoting RNase L expression. On the other hand, the suppressive machinery overproduces RLI to inhibit the activity of RNase L. As a result, both RNase L and RLI are highly expressed in lung cancer cells. The unique regulatory mode may provide a special strategy to treat lung cancer by promoting the activity of RNase L through suppression of RLI.

\section{Conflict of interest}

None.

\section{Acknowledgement}

This work was supported by a grant from Tongji University Foundation to YD.

\section{References}

[1] Youlden DR, Cramb SM, Baade PD. The international epidemiology of lung cancer: geographical distribution and secular trends. J Thorac Oncol 2008;3:819-31.
[2] Jemal A, Siegel R, Ward E, Hao Y, Xu J, Thun MJ. Cancer statistics, 2009, CA. Cancer J Clin 2009;59:225-49.

[3] Egleston BL, Meireles SI, Flieder DB, Clapper ML. Population-based trends in lung cancer incidence in women. Semin Oncol 2009;36:506-15.

[4] Scagliotti GV, Longo M, Novello S. Nonsmall cell lung cancer in never smokers. Curr Opin Oncol 2009;21:99-104.

[5] Li ZG, Zhao J, Du YH, Park HR, Sun SY, Bernal-Mizrachi L, et al. Down-regulation of $14-3-3 \zeta$ suppresses anchorage- independent growth of lung cancer cells through anoikis activation. PNAS 2008;105:162-7.

[6] Karna P, Sharp SM, Yates C, Prakash S, Aneja R. EM011 activates a survivindependent apoptotic program in human non-small cell lung cancer cells. Mol Cancer 2009;8:93.

[7] Bhattacharya R, Kowalski J, Larson AR, Brock M, Alani RM. Id1 promotes tumor cell migration in nonsmall cell lung cancers. J Oncol 2010;2010:856105.

[8] Okudela K, Yazawa T, Ishii J, Woo T, Mitsui H, Bunai T, et al. Down-regulation of FXYD3 expression in human lung cancers: its mechanism and potential role in carcinogenesis. Am J Pathol 2009;175:2646-56.

[9] Carpten J, Nupponen N, Isaacs S, Sood R, Robbins C, Xu J, et al. Germline mutations in the ribonuclease L gene in families showing linkage with HPC1. Nat Genet 2002;30:181-4.

[10] Rokman A, Ikonen T, Seppala EH, Nupponen N, Autio V, Mononen N, et al. Germline alterations of the RNASEL gene, a candidate HPC1 gene at $1 \mathrm{q} 25$, in patients and families with prostate cancer. Am J Hum Genet 2002;70:1299-304.

[11] Daugherty SE, Hayes RB, Yeager M, Andriole GL, Chatterjee N, Huang WY, et al. RNASEL Arg462Gln polymorphism and prostate cancer in PLCO. Prostate 2007;67:849-54.

[12] Xiang Y, Wang Z, Murakami J, Plummer S, Klein EA, Carpten JD, et al. Effects of RNase L mutations associated with prostate cancer on apoptosis induced by 2',5'-oligoadenylates. Cancer Res 2003;63:6795-801.

[13] Krüger S, Silber AS, Engel C, Görgens H, Mangold E, Pagenstecher C, et al. Arg462Gln sequence variation in the prostate-cancer-usceptibility gene RNASEL and age of onset of hereditary non-polyposis colorectal cancer: a casecontrol study. Lancet Oncol 2005;6:566-72.

[14] Wang L, Zhou A, Vasavada S, Dong B, Nie H, Church JM, et al. Elevated levels of $2^{\prime}, 5^{\prime}$-linked oligoadenylate-dependent ribonuclease L occur as an early event in colorectal tumorigenesis. Clin Cancer Res 1995;1:1421-8.

[15] Zhou A, Paranjape JM, Hassei BA, Nie H, Shan S, Galinski B, et al. Impact of Rnase $\mathrm{L}$ overexpression on viral and cellular growth and death. J Interf Cytok Res 1998;18:953-61.

[16] Hassel BA, Zhou A, Sotomayor C, Maran A, Silverman RH. A dominant negative mutant of 2-5A-dependent RNase suppresses antiproliferative and antiviral effects of interferon. EMBO J 1993;12:3297-304.

[17] Zhou A, Paranjape J, Brown TL, Nie H, Naik S, Dong B, et al. Interferon action and apoptosis are defective in mice devoid of $2^{\prime}, 5^{\prime}$-oligoadenylate-dependent RNase L. EMBO J 1997;16:6355-63.

[18] Li XL, Blackford JA, Hassel BA. RNase L mediates the antiviral effect of interferon through a selective reduction in viral RNA during encephalomyocarditis virus infection. J Virol 1998;72:2752-9.

[19] Li XL, Blackford JA, Judge CS, Liu M, Xiao W, Hassel BA. RNase-L-dependent destabilization of interferon-induced mRNAs. A role for the 2-5A system in attenuation of the interferon response. J Biol Chem 2000;275: 8880-8.

[20] Andersen JB, Mazan-Mamczarz K, Zhan M, Gorospe M, Hassel BA. Ribosomal protein mRNAs are primary targets of regulation in RNase-L-induced senescence. RNA Biol 2009;6:305-15.

[21] Leitner WW, Hwang LN, Deveer MJ, Zhou A, Silverman RH, Williams BRG, et al. Alphavirus-based DNA vaccine breaks immunological tolerance by activating innate antiviral pathways. Nat Med 2003;9:33-9.

[22] Bisbal C, Martinand C, Silhol M, Lebleu B, Salehzada T. Cloning and characterization of a RNAse $\mathrm{L}$ inhibitor. A new component of the interferon-regulated 2-5A pathway. J Biol Chem 1995;270:13308-17.

[23] Ren Y, Li Y, Tian D. Role of the ABCE1 gene in human lung adenocarcinoma. Oncol Rep 2012;27:965-70.

[24] Maor D, Klein ME, Kenady DE, Chretien PB, Mardiney MR. Carcinoma of the lung and cigarette smoking effect on serum ribonuclease activity. JAMA 1978:239:2766-8.

[25] Rusch L, Dong B, Silverman RH. Monitoring activation of ribonuclease L by $2^{\prime}, 5^{\prime}$-oligoadenylates using purified recombinant enzyme and intact malignant glioma cells. Methods Enzymol 2001;342:10-20.

[26] Urisman A, Molinaro RJ, Fischer N, lummer SJP, Casey G, Klein EA, et al. Identification of a novel gammaretrovirus in prostate tumors of patients homozygous for R462Q RNASEL variant. PLoS Pathog 2006;2:e25.

[27] Dong B, Silverman RH. 2-5A-dependent RNase molecules dimerize during activation by 2-5A. J Biol Chem 1995;270:4133-7.

[28] Silverman RH, Zhou A, Auerbach MB, Kish D, Gorbachev A, Fairchild RL. Skin allograft rejection is suppressed in mice lacking the antiviral enzyme, $2^{\prime}, 5^{\prime}-$ oligoadenylate-dependent RNase L. Viral Immunol 2002:15:77-83.

[29] Li XL, Ezelle HJ, Kang TJ, Zhang L, Shirey KA, Harro J, et al. An essential role for the antiviral endoribonuclease RNase-L, in antibacterial immunity. PNAS 2008;105:20816-21.

[30] Madsen BE, Ramos EM, Boulard M, Duda K, Overgaard J, Nordsmark M, et al. Germline mutation in RNASEL predicts increased risk of head and neck uterine cervix and breast cancer. PLoS One 2008;3:e2492.

[31] Martinand C, Salehzada T, Silhol M, Lebleu B, Bisbal C. RNase L inhibitor (RLI) antisense constructions block partially the down regulation of the 2-5A/RNase 
L pathway in encephalomyocarditis-virus (EMCV)-infected cells. Eur J Biochem 1998;254:238-47.

[32] Martinand C, Montavon C, Salehzada T, Silhol M, Lebleu B, Bisbal C. RNase $\mathrm{L}$ inhibitor is induced during human immunodeficiency virus type 1 infection and down regulates the 2-5A/RNase L pathway in human T cells. J Virol 1999;73:290-6.

[33] Casey G, Neville PJ, Plummer SJ, Xiang Y, Krumroy LM, Klein EA. RNASEL Arg462Gln variant is implicated in up to $13 \%$ of prostate cancer cases. Nat Genet 2002;32:581-3.
[34] Rennert H, Bercovich D, Hubert A, Abeliovich D, Rozovsky U, Bar-Shira A et al. A novel founder mutation in the RNASEL gene, 471delAAAG, is associated with prostate cancer in Ashkenazi Jews. Am J Hum Genet 2002;71: 981-4.

[35] Gileadi O, Lorberboum H, de Groot N, Hochberg AA. Location of RNase and RNase inhibitor on free cytoplasmic mRNA-protein particles from human placenta. Mol Biol Rep 1984;9:241-4.

Post-print standardized by MSL Academic Endeavors, the imprint of the Michael Schwartz Library at Cleveland State University, 2017. 